\section{Carl Jung and Alcoholics Anonymous: is a Theistic Psychopathology Feasible?}

Received: January 26, 2016; Accepted: January 27, 2016; Published: February 04, 2016

The reputed success in rehabilitating so-called "hopeless" alcoholics through the Alcoholics Anonymous (A.A.) program depends in large measure to convincing the members of the group or community that they are totally helpless in changing themselves through their own efforts, but that God can do it when they give themselves and their lives over to God. This theistic approach and method may influence future theory and practice in psychopathology and psychiatry, as this aspect of Carl Jung's psychology [1] becomes the focus of attention.

In a letter to Carl Jung that was recently made public on the Web, Bill Wilson, founder of A.A., reminds Jung of a conversation that Jung had 30 years before with one of his patients who was an alcoholic: "That conversation between you was to become the first link in the chain of events that led to the founding of Alcoholics Anonymous". Wilson specifies further: "My recollection of his account of that conversation is this: First of all, you frankly told him of his hopelessness, so far as any further medical or psychiatric treatment might be concerned. ... When he then asked you if there was any other hope, you told him that there might be, provided he could become the subject of a spiritual or religious experience - in short, a genuine conversion. You pointed out how such an experience, if brought about, might remotivate him when nothing else could."

Jung confirms in his answer to Wilson that the conversation was "adequately reported" by his patient. We can conclude from this, as well as other autobiographical data, that Jung was a deeply religious man, that he had undergone religious conversion, and that he obtained motivation or strength from his personal relationship with God. At the same time, Jung's letter reveals his lifelong preoccupation with keeping his relationship with God from appearing openly in his practice, lectures, and writings. He was focused on the ambitious work of constructing new psychological knowledge that can appear as scientific, and this cannot be based on merely personal or subjective experience, either his own or that of a visionary or mystic. He had to be careful not to have his psychiatric practice be based on religion or his own religious conversion.

About that conversation with his alcoholic patient, Jung informs Bill Wilson that "I could not tell him everything...In those days I had to be exceedingly careful of what I said." Jung was concerned of his reputation and did not want being misunderstood or
Leon James

College of Social Sciences, Department of Psychology, University of Hawaii, USA

\section{Corresponding Author: Leon James}

”. leon@hawaii.edu

Professor, College of Social Sciences, Department of Psychology, University of Hawaii, USA.

Citation: James L. Carl Jung and Alcoholics Anonymous: is a Theistic Psychopathology Feasible? Acta Psychopathol. 2016, 2:1.

misreported. In his letter, Jung reveals that at that time he did not feel comfortable saying the following to his patient: "His craving for alcohol was the equivalent of ... the spiritual thirst of our being for wholeness, expressed ... as the union with God."

Jung shares his conviction that "the evil principle prevailing in this world leads the unrecognized spiritual need into perdition, if it is not counteracted by a real religious insight". Jung saw "real religious insight" as involving a personal and meaningful relationship with God. Jung states that "these are the reasons why I could not give a full and sufficient explanation to Roland $H$. but I am risking it with you".

It is noteworthy that Jung ends his letter to Bill Wilson with this statement:

"Alcohol in Latin is "spiritus" and you use the same word for the highest religious experience as well as for the most depraving poison. The helpful formula therefore is: spiritus contra spiritum."

This title in Latin encapsulates Jung's theistic psychiatry and scientific dualism. He is acknowledging thereby the existence of spiritual good and evil that is powerfully active in the mind of individuals. God's angelic forces of good ("spiritus") battle the devil's infernal forces of evil (spirit alcohol). In this view, the human mind is a battleground between societies of good spirits and hoards of evil spirits that exist in the collective unconscious of humanity. This would lead to the conclusion that mental alcoholism is a spiritual disease caused by evil psychic forces in the collective unconscious that have attacked an individual and are holding him or her as a mental prisoner.

The first two steps of the 12-step program are the most critical, which is why they are placed in rank 1 and 2 . It is declared that nothing can succeed in the other steps without these first two. 
There is the warning that the tragic long painful failure of the alcoholic man and woman will continue if the first two steps are not completed. The first step is to declare psychological bankruptcy or failure. This must come after years of seeing one's life break apart at the seams despite our desperate attempts to control our mental sickness. We must admit defeat to ourselves. We must see that we are completely hopeless trying to solve our problem by ourselves. That is step 1 . Nothing goes without it. To admit hopelessness, and to actually mean it, is to give up delusional arrogance and obsessive self-pride. Now there is room for step 2.

Step 2 is to replace the self that is at the helm of our mind, with God being at the helm. This is the confession and admission of the existence of a "Higher Power", higher than one's own power. The quote below from the official A.A. guidebook shows up various types of mental conflicts that new AA members have regularly experienced in the form of rebelling against faith, invocation, and reliance on God. It is asserted that nearly everyone has a culture of religion from childhood but many have in their adult life departed from that "childish" idea of God. This constitutes an intellectual rejection of God. Others experience an emotional rejection because God wouldn't do what they asked Him for, or worse, God did not protect their loved ones from disaster and early death [2].

The guidebook asserts that all this psychological resistance is just that, resistance. It does not present an actual obstacle that prevents the solution. With practice and group support the new members gain courage in dethroning themselves from their delusional status of self-power, and this internal action allows God into their thinking and emoting. Now help is given on a daily basis through affective strength and self-confidence that relies on God. The process of psychopathological recovery has begun and continues endlessly.

The official A.A. Guide points to the ineffectiveness of traditional religious interventions with alcoholics. They insist that these have no power over the sickness. In contrast to this, a personal relationship with God does have the power to heal the mental and spiritual sickness of the alcoholic victim.

To clergymen, doctors, friends, and families, the alcoholic who means well and tries hard is a heartbreaking riddle. To most A.A.'s, he is not. There are too many of us who have been just like him, and have found the riddle's answer. This answer has to do with the quality of faith rather than its quantity. This has been our blind spot. We supposed we had humility when really we hadn't. We supposed we had been serious about religious practices when, upon honest appraisal, we found we had been only superficial. Or, going to the other extreme, we had wallowed in emotionalism and had mistaken it for true religious feeling. In both cases, we had been asking something for nothing. The fact was we really hadn't cleaned house so that the grace of God could enter us and expel the obsession. In no deep or meaningful sense had we ever taken stock of ourselves, made amends to those we had harmed, or freely given to any other human being without any demand for reward. We had not even prayed rightly. We had always said, "Grant me my wishes" instead of "Thy will be done." The love of God and man we understood not at all. Therefore we remained self-deceived, and so incapable of receiving enough grace to restore us to sanity.

Therefore, Step Two is the rallying point for all of us. Whether agnostic, atheist, or former believer, we can stand together on this Step. True humility and an open mind can lead us to faith, and every A.A. meeting is an assurance that God will restore us to sanity if we rightly relate ourselves to $\mathrm{Him}$.

Jung describes "faith" or religious belief as a psychological process that goes through two phases of development. First, in the initial phase, people believe that they are "saved" because of their faith and the strength of their self-confidence in that belief. This initial phase is a superficial state that does not penetrate into the interior levels of personality structure from where we derive our motivations and emotions. This initial phase is immature and selfcentered because people do not yet have the deep capacity for mutual love or respect for others. They are still focused exclusively on gaining dominance over everyone else for the sake of selfgain and self-supremacy. A.A. follows the universal principle that every human being is born with the mental predisposition to do all things for the sake of self, and if not for the sake of self, then for the sake of others who are allied to self, thus ultimately for the sake of self. This selfishness is unhealthy and injurious to the individual's psychological well-being and functioning. Selfishness is also destructive of society and community, thus of the entire human race.

The $A . A$. guidebook asserts that those who are motivated to leave this self-injurious and self-limiting phase behind can enter the "inner chamber" in their mind, initiating a sincere relationship with God. The influence of God in the individual's mind challenges and confronts the self-centered and self-serving focus. The person then experiences a spiritual battle or psychological conflict in the form of the temptation to act contrary to spiritual principles for the sake of satisfying some selfish love or interest. This is the level of the psychological and spiritual battle that the alcoholic faces daily. This is where the A.A. group and community values and rationales need to be acquired and practiced.

In 1937 Jung wrote: "People sometimes call me a religious leader. I am not that. I have no message, no mission; only an attempt to understand. We are philosophers in the old sense of the word, lovers of wisdom. That avoids the sometimes questionable company of some who offer a religion".

In 1999 Anthony Storr, a well-known Jung interpreter, wrote: "Analytical psychology does not aim at curing neurotic symptoms, but at bringing about a change in the patient's attitude to him or herself, and therefore to life in general. This new attitude can be described as 'religious', but it has nothing to do with creeds or conventional forms of worship. Analytical psychology is not a religion, but can be described as a prolegomenon to religion or religion in statu nascendi."

A 2005 book published by the American Psychological Association makes this statement about Jung: "Personality development and psychopathology cannot be seen in purely secular terms, and no longer can psychotherapy be considered a purely secular pursuit. ... Within the Jungian perspective, the removal of symptoms as a final goal of therapy is an incomplete approach. The symptom is 
a wakeup call from the Self to greater consciousness." (L. Corbett \& M. Stein, Contemporary Jungian approaches to spiritually oriented psychotherapy).

In 1999, Shamdasani [3] a well-known Jungian commentator wrote this: "Given the significance of religion in people's lives, it followed that a psychology that failed to consider religious phenomena did not deserve to be called a psychology. Thus the psychology of religion was not simply a regional or peripheral domain, but was essential to the possibility of a general psychology. Thus Jung did not approach the topic of religion with a pre-established definition of psychology. Rather, the study of religious phenomena was one of the critical issues that helped define Jung's concept of psychology." 


\section{References}

1 James L (2015) A comparison of keywords in the dynamic psychology of Jung, Swedenborg, and Freud. Journal of Psychology and Clinical Psychiatry 3: 1-13.
2 James L (2015) Jung and Swedenborg on God and Life After Death. Print and Kindle Editions. Amazon Digital Services.

3 Shamdasani S (1999) Is analytical psychology a religion? In statu nascendi. Journal of Analytical Psychology 44: 539-545. 